\title{
PENGUKURAN KAPABILITAS TATA KELOLA TI SISTEM INFORMASI TIRAS DAN TRANSAKSI BAHAN AJAR UNIVERSITAS TERBUKA MENGGUNAKAN COBIT 5
}

\author{
Denisha Trihapningsari ${ }^{* 1}$, Dewi Agushinta R. ${ }^{2}$, Lintang Yuniar Banowosari ${ }^{3}$ \\ ${ }^{1,2,3}$ Universitas Gunadarma Depok \\ Email: 1denishatrihap@gmail.com, ${ }^{2}$ dewiar@staff.gunadarma.ac.id, ${ }^{3}$ lintang@ staff.gunadarma.ac.id \\ *Penulis Korespondensi
}

(Naskah masuk: 14 Februari 2020, diterima untuk diterbitkan: 15 Oktober 2021)

\begin{abstract}
Abstrak
Layanan bahan ajar Universitas Terbuka (UT) menerapkan Sistem Informasi Tiras dan Transaksi Bahan Ajar (SITTA) yang dalam prosesnya ditemui masalah terkait operasional dan optimalisasi Teknologi Informasi. Oleh sebab itu evaluasi perlu dilakukan untuk mengetahui sejauh mana sistem telah memenuhi kebutuhan organisasi tata kelola TI. Sebelumnya sistem belum pernah dievaluasi menggunakan mekanisme kontrol audit sistem informasi dengan framework COBIT 5. Penelitian ini bertujuan untuk mengukur tingkat kapabilitas tata kelola TI SITTA menggunakan framework COBIT 5. Fokus evaluasi pada sistem ini yaitu terkait manajemen layanan TI sehingga disepakati untuk mengevaluasi domain proses EDM01, EDM04, DSS01, DSS02, dan DSS03. Hasil penelitian diperoleh kapabilitas proses EDM01, EDM04, dan DSS01 saat ini berada di level performed process (level 1), proses DSS02 dan DSS03 berada di level managed process (level 2). Capaian tingkat kapabilitas yang diharapkan manajemen untuk proses yang dievaluasi tersebut yaitu level optimizing process (level 5). Hal ini menunjukkan bahwa organisasi belum sepenuhnya menerapkan beberapa best practices untuk tujuan proses yang dievaluasi, meski telah ada standar layanan tata kelola TI namun belum dapat diimplementasikan secara maksimal. Rekomendasi aktivitas kebijakan tata kelola layanan TI yang diperoleh dari penelitian ini diharapkan menjadi referensi prosedur monitoring dan pengukuran kemampuan TI di layanan bahan ajar UT yang lebih bersifat efektif dan implementatif. Penelitian ini menghasilkan pengukuran tingkat kapabilitas proses TI pada COBIT 5 domain terpilih, analisis kondisi organisasi untuk capaian tingkat kapabilitas proses, kriteria prioritas perbaikan, dan rekomendasi perbaikan untuk tiap proses agar dapat mencapai level kapabilitas optimizing process (level 5) di kemudian hari.
\end{abstract}

Kata kunci: Framework COBIT 5, Tata Kelola Teknologi Informasi, Kapabilitas Proses, Rekomendasi Perbaikan

\section{IT GOVERNANCE CAPABILITY MEASUREMENT USING COBIT 5 FRAMEWORK (CASE STUDY: INFORMATION SYSTEM OF TIRAS AND TEACHING MATERIALS TRANSACTIONS IN UNIVERSITAS TERBUKA)}

\begin{abstract}
The Open University (UT) teaching material service implements the Information System for Learning Materials and Transactions (SITTA) which in the process encountered problems related to the operation and optimization of Information Technology. Therefore, it is necessary to evaluate to determine the extent to which the system has met the needs of the IT governance organization. The SITTA system had never been evaluated before using an information system audit control mechanism with the COBIT 5 framework. This study aims to measure the level of SITTA IT governance capabilities using the COBIT 5 framework. The focus of evaluation on the system is related to IT service management so it was agreed to evaluate the domain of the EDM01, EDM04, DSSO1, DSSO2, and DSSO3 processes. The results showed that the capabilities of the EDMO1, EDM04, and DSSO1 processes are currently at the performed process level (level 1), while the DSSO2 and DSSO3 processes are at the managed process level (level 2). The achievement of the capability level is expected by management for the process being evaluated is the optimizing process level (level 5). It can be shown that the organization has not fully implemented some best practices for the process being evaluated, even there are already IT governance service standards but it has not been implemented optimally. The recommendations for IT service governance policy activities obtained from this study are expected to become a reference for monitoring procedures and measuring IT capabilities in UT teaching material services that are more effective and implemented. This
\end{abstract}


research produces measurement of IT process capability level in selected COBIT 5 domains, analysis of organizational conditions to achieve process capability level, improvement priority criteria, and recommendations for improvement for each process to achieve optimizing process capability level (level 5) in the near future.

Keywords: COBIT 5 Framework, Information Technology Governance, Process Capability, Improvement Recommendations

\section{PENDAHULUAN}

Perkembangan teknologi yang semakin modern diiringi dengan kemajuan era digitalisasi informasi mendorong masyarakat, pelaku usaha, bahkan institusi akademik untuk ikut beradaptasi dan meningkatkan produktivitasnya dalam penerapan di bidang sistem informasi. Menurut (IT et al., 2012), dalam rangka mendukung aktivitas sebuah organisasi, informasi menjadi bagian yang penting bagi perkembangan organisasi. Manfaat dari teknologi informasi dalam peningkatan layanan dan proses kerja suatu organisasi berpengaruh untuk menunjang kinerja suatu organisasi. Penerapan dari sistem dan tata kelola teknologi informasi sangat membantu aktivitas proses bisnis, akan tetapi perlu disadari bahwa suatu sistem informasi perlu untuk ditinjau/dievaluasi kembali sampai mana proses tersebut berjalan untuk mengetahui sejauh mana sistem tersebut telah memenuhi kebutuhan organisasi agar ke depannya dapat dilakukan pengembangan sistem dengan perolehan hasil yang lebih optimal. Oleh sebab itu, penerapan mekanisme audit sistem informasi dirasa perlu untuk dilakukan untuk peninjauan kembali (evaluasi) pada sistem informasi yang saat ini sedang berjalan.

Hal yang berhubungan dengan tata kelola TI memerlukan mekanisme audit pengelolaan teknologi informasi. Control Objective for Information and Related Technology atau COBIT diartikan sebagai framework TI yang dirilis oleh ISACA dan dapat digunakan sebagai alat bantu organisasi dalam melakukan evaluasi penilaian TI yang optimal untuk memperoleh keseimbangan antara manfaat yang di inginkan dan mengoptimalkan penggunaan sumber daya dan nilai tingkat risiko (ISACA, 2012a). Di dalam COBIT terdapat sekumpulan dokumen Best Practice untuk IT Governance (tata kelola TI) yang digunakan untuk membantu Auditor, User, dan Manajemen serta berfungsi sebagai gap antara resiko bisnis, kebutuhan kontrol dan masalah yang ada pada teknis sistem TI (ISACA, 2012b). Menurut penelitian yang telah dilakukan, COBIT 5 dapat memberi evaluasi keadaan tata kelola Teknologi Informasi sekaligus memberi masukan yang dapat digunakan untuk perbaikan di masa mendatang (Surjandy et al., 2020).

Universitas Terbuka (UT) sebagai salah satu Perguruan Tinggi Negeri menerapkan sistem Pendidikan Terbuka dan Jarak Jauh atau biasa dikatakan dengan sistem PTJJ. Sistem PTJJ yang dimiliki UT membuat UT memiliki perbedaan dengan institusi pendidikan tinggi tatap muka. Di UT, bahan ajar menjadi sumber belajar utama bagi mahasiswa. Dengan adanya bahan ajar yang dirancang UT secara khusus, mahasiswa dapat dengan mudah mempelajari materi dan belajar secara mandiri. Hal itu membuat UT lebih banyak aktivitas tutorial online (tutor online) dengan kontribusi nilai $40 \%$ terhadap nilai Ujian Akhir Semester (UAS) yang dapat diakses oleh mahasiswa melalui laman web https://elearning.ut.ac.id/.

Karena bahan ajar menjadi hal yang utama bagi mahasiswa, maka UT mewajibkan mahasiswa untuk membeli buku berupa Buku Materi Pokok (BMP) dan bahan ajar pendukung lain dengan sistem Wajib Beli (WB) melalui terbitnya pesanan nomor Delivery Order (DO). DO inilah yang menjadi acuan dalam aktivitas operasional layanan bahan ajar mahasiswa yang dikelola oleh salah satu unit UT yaitu Pusat Layanan Bahan Ajar (Puslaba). Puslaba memiliki peran utama dalam mengelola layanan dan mendistribusikan kebutuhan bahan ajar bagi mahasiswa. Dalam mengelola layanan tersebut, Puslaba memiliki fasilitas layanan dalam bidang teknologi informasi yaitu Sistem Informasi Tiras dan Transaksi Bahan Ajar (SITTA) dan tersedia dalam bentuk layanan aplikasi web yang dapat diakses melalui jaringan internal UT di pusat dan 39 kantor lokasi UPBJJ-UT.

Berdasarkan hasil observasi dari aktivitas layanan bahan ajar, tata kelola TI pada layanan bahan ajar belum dikelola secara baik dan maksimal sehingga masih ditemui adanya permasalahan dalam manajemen dan operasional pelaksanaan. Permasalahan terkait optimalisasi teknologi seperti melakukan pengembangan aplikasi berbasis mobile belum dapat dilakukan secara maksimal karena keterbatasan sumber daya (developer) yang ada. Aplikasi web SITTA pada kondisi tertentu perlu dilakukan pemeliharaan ketika terjadi masalah dan adanya penyesuaian penambahan fitur (menu) di tengah aktivitas proses yang sedang berjalan. Selain itu kapasitas bandwith yang rendah juga membuat waktu traffic dan transfer data aplikasi menjadi lambat. Permasalahan operasional lain diantaranya belum adanya sistem operasi kendali pekerjaan untuk kebutuhan update pekerjaan di unit Puslaba, belum dilakukan pemantauan kerja secara langsung ke vendor pengiriman bahan ajar sehingga ditemukan adanya ketidakcocokan dokumen antara fisik dan real di lapangan, fasilitas tracking/pelacakan pengiriman bahan ajar yang 
dikirim ke alamat mahasiswa secara teknologi belum berfungsi dengan maksimal pada aplikasi mobile dan web yang salah satunya dikarenakan belum terintegrasinya sistem API milik vendor pengiriman dengan aplikasi SITTA, adanya delay update karena petugas di gudang ketika mengambil dan memproses bahan ajar harus kembali ke Personal Computer (PC) untuk melakukan update data, dan adanya keterbatasan sumber daya yang mampu dalam bidang TI terutama terkait hal inovasi pengembangan TI pada SITTA.

Pusat Layanan Bahan Ajar UT berharap teknologi informasi dapat memberikan kontribusi yang maksimal bagi kelangsungan aktivitas operasional unit dan berharap peran TI dapat menyesuaikan dengan kebijakan tata kelola manajemen TI pada layanan bahan ajar UT yang meliputi lingkup manajemen hardware, software, dan brainware. Dalam rangka memperoleh implementasi tata kelola TI yang baik, evaluasi pada aktivitas layanan dan distribusi bahan ajar perlu segera dilakukan untuk peningkatan kinerja dan layanan berbasis teknologi informasi. Hal ini menjadi peluang untuk mewujudkan sasaran mutu dan kualitas manajemen yang baik sesuai standar tata kelola TI. Dalam penelitian yang dibuat Fenny dan Johanes (2017) terdapat pernyataan menurut IT Governance Institute (ITGI), bahwa IT Governance atau tata kelola Teknologi Informasi menginstitusikan dan mengintegrasikan praktik yang baik untuk memastikan TI mendukung tujuan usaha suatu organisasi.

Penelitian yang telah dilakukan sebelumnya mengenai tata kelola TI menggunakan framework COBIT 5 diantaranya adalah penelitian oleh (Astuti et al., 2019) yang membahas terkait evaluasi TI dengan kerangka kerja COBIT 5, berfokus pada studi kasus PT. Garam (Persero) yaitu proses DSS02, DSS03, dan DSS04. Hasil pengukuran level kapabilitas menyimpulkan capability level yang diperoleh dari proses subdomain DSS02, DSS03, dan DSS04 adalah 1 dan pada setiap proses subdomain memiliki nilai GAP sebesar 1. Penelitian ini menghasilkan rekomendasi dan melakukan pelengkapan pendokumentasian dokumen output work product.

Penelitian lainnya yaitu mengenai tata kelola di lingkungan Universitas juga pernah dilakukan dengan menggunakan framework COBIT 5 dan ISO 38500 (Ardima, Gernowo, Slamet, 2020). Penelitian ini mengukur tingkat kapabilitas tata kelola TI pada Sistem Informasi di UPT TIK Universitas Negeri Semarang. Hasil penelitian diperoleh 17 domain COBIT 5 memiliki tingkat kapabilitas level 2 yaitu ada pada tingkat managed process, dimana institusi telah melakukan perencanaan, pengontrolan dan penyesuaian terhadap proses TI yang sedang berjalan.

Selanjutnya penelitian lainnya membahas mengenai evaluasi tata kelola TIK di lingkungan
Kantor Kecamatan Baturraden (Fajarwati et al., 2018). Penelitian ini menghasilkan kesimpulan evaluasi yaitu berupa tingkat kapabilitas yang telah dicapai oleh proses yang dievaluasi (EDM01, EDM02, EDM03, dan EDM05) dan saat itu implementasi teknologi informasinya memperoleh nilai sebesar 1,75 atau berada pada tingkat 1 (proses berjalan/ performed).

Penelitian lain yang sejenis terkait COBIT 5 juga telah dilakukan mengenai evaluasi tingkat maturitas tata kelola TI di Pusat Sistem Informasi (PSI) STMIK Mikroskil (Nyonawan et al., 2018). Pada penelitian ini digunakan alat ukur Process Assessment Model untuk mengukur capaian proses yang dievaluasi dengan hasil EDM01 ada pada level 3 (Established Process).

Berdasarkan permasalahan yang telah dipaparkan, layanan bahan ajar UT perlu dilakukan sebuah mekanisme yang dapat membantu kontrol audit dan evaluasi pada tata Kelola TI agar ke depannya sistem dapat berjalan lebih baik lagi, mengingat penggunaan TI dapat memberikan kontribusi maksimal bagi layanan Universitas Terbuka ke mahasiswa. Tata Kelola TI pada Sistem Informasi Tiras dan Transaksi Bahan Ajar (SITTA) di UT sebelumnya memang belum pernah dilakukan evaluasi menggunakan alat ukur (tool) kapabilitas dengan model COBIT 5. Oleh karena itu penelitian ini dilakukan dengan maksud untuk mengukur kapabilitas tata kelola TI pada proses kegiatan layanan dan distribusi bahan ajar UT yang terdiri dari evaluasi implementasi aplikasi SITTA dan mekanisme pemanfaatan sumber daya (hardware, software, dan brainware) yang berbasis TI sebagai objek penelitian menggunakan model referensi COBIT 5 serta memberikan rekomendasi perbaikan untuk pengembangan sistem di masa mendatang. Penelitian yang dilakukan oleh (Putri et al., 2019) menjelaskan bahwa setiap atribut yang ada pada tiap level dinilai menggunakan skala peringkat (rating scale) yang terdefinisi pada standar ISO/IEC 15504. COBIT 5 menggunakan ISO/ IEC 15504 sebagai alat ukur tingkat kemampuan di setiap proses (domain) saat evaluasi karena pengukuran dengan ISO/ IEC 15504 dapat memastikan hasil pengukuran yang lebih obyektif, imparsial, konsisten, repeatable, dan dapat merepresentasikan proses yang diukur (ISO/IEC 15504-2, 2003) (ISACA, 2013).

Penulisan ini memiliki tujuan seperti berikut:

1. Mengukur tingkat kapabilitas pada kinerja tata kelola TI SITTA yang sedang berjalan saat ini pada pusat layanan bahan ajar UT dengan menggunakan model referensi COBIT 5 sebagai aturan standar dan alat ukur Process Assessment Model (PAM) untuk mengukur tingkat kapabilitas proses.

2. Mengidentifikasi praktik tata kelola TI yang berjalan, sehingga dapat memberikan saran/ rekomendasi perbaikan dan peningkatan 
sistem layanan pada proses kegiatan TI dengan mengacu pada best practice berdasarkan model referensi COBIT 5 untuk memberikan hasil lebih baik dan terstruktur pada pengelolaan TI di unit Puslaba-UT serta dapat mengatasi permasalahan yang ada sesuai dengan proses COBIT 5 relevan.

\section{METODE PENELITIAN}

\subsection{Tahapan Penelitian}

Tahapan yang dilakukan pada penelitian ini dilakukan dengan langkah-langkah seperti pada Gambar 1 .

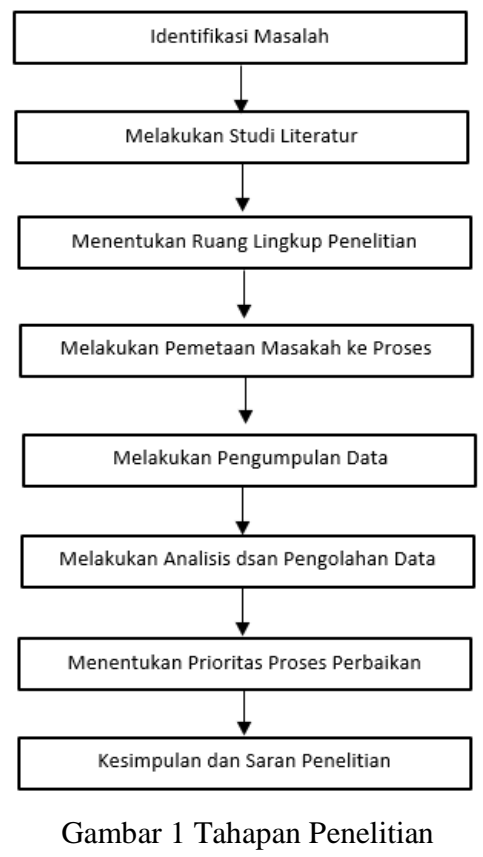

Gambar 1 menunjukkan tahapan penelitian yang dilakukan, sebagai berikut:

1. Identifikasi Masalah

Tahap identifikasi masalah dilakukan untuk mengetahui masalah yang ada pada sistem pengelolaan bahan ajar dan implementasi SITTA Universitas Terbuka dengan ruang lingkup penelitian pada tata kelola manajemen layanan teknologi informasi Pusat Layanan Bahan Ajar Universitas Terbuka.

2. Melakukan Studi Literatur

Tahap studi literatur dilakukan sebagai bahan referensi dan landasan teori yang digunakan pada penelitian ini terkait framework COBIT 5, pengetahuan mengenai tata kelola dan manajemen teknologi informasi, dan landasan teori terkait lainnya yang berhubungan dengan evaluasi tata kelola, seperti teori untuk menghitung skala kapabilitas proses, perolehan hasil kuesioner dengan alat ukur dari Process Assessment Model (PAM) terkait penelitian.

3. Menentukan Ruang Lingkup Penelitian
Menentukan Unit Pusat Pengelolaan Bahan Ajar dan implementasi aplikasi SITTA sebagai studi kasus penelitian.

4. Melakukan Pemetaan Masalah ke Proses Tahapan ini yaitu berupa pemetaan masalah ke proses COBIT 5 terpilih. Pada tahap ini dilakukan perancangan model penelitian dengan cara menyelaraskan kebutuhan pada permasalahan yang ada dengan COBIT 5 pada proses EDM (Evaluate, Direct, \& Monitor) dan proses DSS (Delivery, Service, \& Support) sebagai domain terpilih dan relevan dengan masalah-masalah yang ada.

5. Melakukan Pengumpulan Data

Proses pengumpulan data yang digunakan pada penelitian ini yaitu dengan menggunakan metode observasi, wawancara kepada stakeholder serta kuesioner untuk memperoleh hasil pengukuran tingkat kapabilitas proses pada domain proses terpilih.

6. Melakukan Analisis dan Olah Data Kuesioner Pada tahap ini dilakukan analisis dan olah data kuesioner untuk mengukur tingkat kapabilitas dari proses-proses COBIT 5 terpilih yang relevan dengan masalah-masalah yang ada. Pengukuran dilakukan menggunakan alat ukur Process Assessment Model (PAM) terhadap hasil jawaban responden pada kuesioner COBIT 5. Hasil analisis dan pengolahan data tersebut, kemudian ditentukan target tingkat kapabilitas yang diharapkan sekaligus menganalisis hasil kesenjangan (gap) antara pencapaian proses saat ini (sedang berjalan/as in) dengan tingkat kemampuan yang diharapkan (akan datang/to be) melalui evaluasi sistem tata kelola teknologi informasi pada sistem layanan bahan ajar dan implementasi Sistem Informasi Tiras dan Transaksi Bahan Ajar (SITTA).

7. Menentukan Prioritas Proses Perbaikan Melakukan penentuan prioritas dari proses yang akan dilakukan perbaikan. Dengan begitu dapat terpilih proses mana yang akan dijalankan terlebih dahulu untuk perbaikan. Pemilihan prioritas dilakukan dengan menggunakan metode matriks pemilihan prioritas.

8. Pembuatan Rekomendasi Perbaikan

Melakukan perbaikan pada tiap proses COBIT 5 terpilih yang telah disesuaikan dengan permasalahan/kendala operasional yang ada berkaitan dengan penyediaan fasilitas teknologi informasi dan analisis best practices.

9. Kesimpulan dan Saran

Bagian ini merupakan bagian akhir pada penelitian. Saran berisi penjelasan untuk penelitian selanjutnya yang dapat dilakukan untuk menyempurnakan hasil dari evaluasi manajemen tata kelola teknologi informasi terkait sistem layanan pengelolaan bahan ajar. 


\subsection{Metode Pengumpulan Data}

Pada penelitian ini menggunakan metode pengumpulan data diantaranya sebagai berikut:

1. Metode Observasi

Melakukan aktivitas peninjauan secara langsung pada unit layanan bahan ajar dalam mengelola aktivitas operasional dan proses tata kelola yang sedang berjalan, seperti penggunaan hardware, software, database, network, hotspot, data center, administrasi, laporan kinerja, penanganan masalah aplikasi, dan monitoring sistem.

2. Metode Wawancara

Wawancara dilakukan secara langsung kepada pihak yang berkaitan/ stakeholder dalam pengelolaan sistem layanan bahan ajar. Informasi yang diperoleh digunakan untuk mengidentifikasi kondisi tata kelola TI berdasarkan praktik terbaik/ best practices yang telah dilakukan saat ini. Wawancara dilakukan terhadap dua orang stakeholder yang memiliki latar belakang bidang TIK, memahami arsitektur pengembangan TI dan memiliki kontribusi dalam pengambilan keputusan terkait tata kelola TI, yaitu Kepala Unit UPT-TIK dan Penanggung Jawab Bidang Pemeliharaan UPT-TIK.

3. Metode Kuesioner

Kuesioner didistribusikan kepada stakeholder/ pemangku kepentingan sebagai manajemen strategis yang berperan dalam pengambilan keputusan pada pemeliharaan tata kelola TI sehingga dapat diperoleh penilaian yang jelas untuk dapat mengukur tingkat kapabilitas tata kelola teknologi informasi yang berjalan saat ini pada unit layanan bahan ajar. Kuesioner diberikan kepada tujuh orang stakeholder sebagai pengambil keputusan terkait manajemen strategis dari SITTA.

\subsection{Tahapan Pengolahan Data Kuesioner}

Pengolahan data kuesioner pada penelitian menggunakan langkah-langkah dengan tahapan seperti pada Gambar 2.

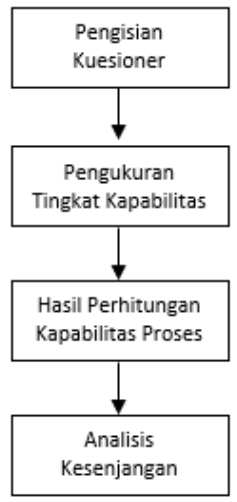

Gambar 2 Tahapan Pengolahan Data

Tahapan pengolahan data pada penelitian ini memiliki penjelasan sebagai berikut:
1. Pengisian Kuesioner

Hasil pengisian kuesioner diperoleh dari jawaban responden penelitian terhadap evaluasi penilaian tata kelola TI pada proses EDM01 Memastikan Pengaturan dan Pemeliharaan Kerangka Tata Kelola, EDM02 - Memastikan Optimalisasi Nilai, DSS01 - Mengelola Operasi, DSS02 - Mengelola Permintaan dan Layanan Insiden, dan DSS03 - Mengelola Masalah. Butir pernyataan pada kuesioner yang didistribusikan telah disesuaikan dengan template standar kuesioner COBIT 5 berdasarkan Self-Assessment Guide.

2. Pengukuran Tingkat Kapabilitas

Hasil dari pengisian kuesioner kemudian dilakukan proses perhitungan tingkat kapabilitas dengan menggunakan alat ukur Process Assessment Model (PAM) pada setiap proses evaluasi terpilih.

3. Hasil Perhitungan Kapabilitas Proses

Hasil perhitungan yang diperoleh dari tingkat kapabilitas proses tata Kelola TI pada sistem layanan bahan ajar dan penggunaan aplikasi SITTA akan diperoleh nilai kapabilitas proses saat ini yang sedang berjalan dan menentukan kapabilitas proses yang diharapkan.

4. Analisis Kesenjangan

Hal ini dilakukan untuk menganalisis nilai ketercapaian proses dengan nilai kapabilitas proses yang diharapkan guna memperoleh rekomendasi dan usulan perbaikan sistem ke depan terkait tata kelola dan manajemen teknologi informasi di setiap permasalahan/ kendala pekerjaan untuk dilakukan evaluasi.

\section{HASIL DAN PEMBAHASAN}

\subsection{Identifikasi Masalah}

Permasalahan diperoleh dari hasil observasi yang dilakukan bersama dengan Penanggung Jawab Bidang Sistem Informasi Data pada Unit Pusat Layanan Bahan Ajar yang memiliki latar belakang dalam bidang teknologi informasi dan memahami arsitektur dan pengembangan teknologi informasi serta memiliki kontribusi dalam pengambilan keputusan implementasi SITTA UT. Masalahmasalah yang diperoleh tersebut diantaranya adalah:

1. Pelaksanaan pengembangan teknologi informasi belum dapat menggunakan perencanaan (planning) yang baik, sehingga membuat stakeholder dapat mengganti kebijakan kerja secara tidak tentu, terlebih ketika pimpinan unit layanan bahan ajar mengalami pergantian.

2. Standar Operasional Prosedur (SOP) yang telah ada terkadang belum dijalankan dengan baik. Selain itu juga belum ada SOP-SOP beserta kelengkapan dokumen terkait mekanisme pengembangan dan pemeliharaan sistem informasi internal. 
3. Sumber daya manusia yang mampu dalam bidang TI masih belum mencukupi dari aspek kualitas.

4. Pengukuran untuk tingkat kesiapan dan kemampuan dari aspek teknologi informasi untuk melayani bahan ajar mahasiswa UT masih dilakukan secara konvensional.

\subsection{Pemetaan Masalah dengan Proses COBIT 5}

Proses terpilih pada COBIT 5 yang dilakukan pada penelitian ini mengacu pada permasalahan/ kendala yang dihadapi Pusat Layanan Bahan Ajar (Puslaba) dalam melayani, mengelola bahan ajar dan hal yang berhubungan dengan penggunaan aplikasi SITTA. Pemetaan atas permasalahan dan kendala yang dihadapi oleh Puslaba terkait manajemen tata kelola dan penggunaan sistem SITTA terhadap proses terpilih ditujukkan seperti Tabel 1 .

Tabel 1 Pemetaan Masalah dengan Proses COBIT

\begin{tabular}{|c|c|c|}
\hline No & Masalah & Proses COBIT \\
\hline 1 & $\begin{array}{l}\text { Pelaksanaan pengembangan } \\
\text { teknologi informasi belum } \\
\text { memiliki master perencanaan } \\
\text { yang baik untuk meningkatkan } \\
\text { kualitas layanan bahan ajar ke } \\
\text { mahasiswa. Selain itu dalam } \\
\text { pelaksanaan SOP belum } \\
\text { terdapat mekanisme yang jelas } \\
\text { terkait pengembangan dan } \\
\text { pemeliharaan tata kelola } \\
\text { teknologi informasi. }\end{array}$ & $\begin{array}{l}\text { EDM01 } \\
\text { (Memastikan } \\
\text { Pengaturan dan } \\
\text { Pemeliharaan } \\
\text { Kerangka Tata } \\
\text { Kelola) }\end{array}$ \\
\hline 2 & $\begin{array}{l}\text { Pemanfaatan sarana digital } \\
\text { dalam bentuk layanan } \\
\text { teknologi informasi yang } \\
\text { belum diterapkan secara } \\
\text { optimal pada beberapa fungsi } \\
\text { kerja dalam melayani dan } \\
\text { mengelola bahan ajar kepada } \\
\text { mahasiswa. }\end{array}$ & $\begin{array}{l}\text { EDM01 } \\
\text { (Memastikan } \\
\text { Pengaturan dan } \\
\text { Pemeliharaan } \\
\text { Kerangka Tata } \\
\text { Kelola) }\end{array}$ \\
\hline 3 & $\begin{array}{l}\text { Keterbatasan sumber daya } \\
\text { manusia, terutama dalam } \\
\text { mengelola dan menggunakan } \\
\text { sarana teknologi informasi, } \\
\text { sehingga masih bergantung } \\
\text { kepada staf yang memiliki } \\
\text { latar belakang di bidang TI. }\end{array}$ & $\begin{array}{l}\text { EDM04 } \\
\text { (Menjamin } \\
\text { optimasi sumber } \\
\text { daya) }\end{array}$ \\
\hline 4 & $\begin{array}{l}\text { Sumber daya yang digunakan } \\
\text { untuk menunjang kegiatan dan } \\
\text { kelangsungan jalannya } \\
\text { operasional pada distribusi } \\
\text { bahan ajar belum optimal } \\
\text { terutama ketika volume } \\
\text { pekerjaan sedang bertambah. }\end{array}$ & $\begin{array}{l}\text { EDM04 } \\
\text { (Menjamin } \\
\text { optimasi sumber } \\
\text { daya) }\end{array}$ \\
\hline 5 & $\begin{array}{l}\text { Optimalisasi proses waktu } \\
\text { belanja/order picking bahan } \\
\text { ajar yang belum dilakukan } \\
\text { dengan baik sehingga } \\
\text { efektivitas waktu jika } \\
\text { menangani DO dalam jumlah } \\
\text { banyak belum dapat memenuhi } \\
\text { target kerja. }\end{array}$ & $\begin{array}{l}\text { DSS01 } \\
\text { (Mengelola } \\
\text { Operasional) }\end{array}$ \\
\hline 6 & $\begin{array}{l}\text { Proses pengambilan barang/ } \\
\text { order picking masih } \\
\text { berdasarkan pengambilan satu- } \\
\text { persatu nomor DO sesuai } \\
\text { dengan nomor batch DO. }\end{array}$ & $\begin{array}{l}\text { DSS01 } \\
\text { (Mengelola } \\
\text { Operasional) }\end{array}$ \\
\hline
\end{tabular}

\begin{tabular}{|c|c|c|}
\hline No & Masalah & Proses COBIT \\
\hline 7 & $\begin{array}{l}\text { Adanya delay update data } \\
\text { dikarenakan petugas } \mathrm{di} \\
\text { Gudang saat mengambil/ order } \\
\text { picking dan memproses bahan } \\
\text { ajar harus kembali ke PC } \\
\text { (Personal Computer) untuk } \\
\text { melakukan updating data. }\end{array}$ & $\begin{array}{l}\text { DSS01 } \\
\text { (Mengelola } \\
\text { Operasional) }\end{array}$ \\
\hline 8 & $\begin{array}{l}\text { Ketersediaan item bahan ajar } \\
\text { yang belum dapat dikendalikan } \\
\text { dengan baik. }\end{array}$ & $\begin{array}{l}\text { DSS01 } \\
\text { (Mengelola } \\
\text { Operasional) }\end{array}$ \\
\hline 9 & $\begin{array}{l}\text { Masih terdapat mahasiswa } \\
\text { yang melakukan layanan } \\
\text { keluhan/ pengaduan pada } \\
\text { informasi pengiriman bahan } \\
\text { ajar melalui nomor help desk } \\
\text { Layanan Bahan Ajar dan } \\
\text { aplikasi Hallo UT pada SIAP } \\
\text { Contact Center yang dieskalasi } \\
\text { ke Unit Pusat Layanan Bahan } \\
\text { Ajar. }\end{array}$ & $\begin{array}{l}\text { DSS02 } \\
\text { (Mengelola } \\
\text { Permintaan } \\
\text { Layanan dan } \\
\text { Insiden) }\end{array}$ \\
\hline 10 & $\begin{array}{l}\text { Proses pengambilan barang/ } \\
\text { order picking dilakukan sesuai } \\
\text { dengan preferensi petugas } \\
\text { yang ditugaskan (belum ada } \\
\text { rules yang jelas dan pasti). }\end{array}$ & $\begin{array}{l}\text { DSS03 } \\
\text { (Mengelola } \\
\text { Masalah) }\end{array}$ \\
\hline 11 & $\begin{array}{l}\text { Layanan bahan ajar UT saat ini } \\
\text { belum memiliki sistem } \\
\text { kontrol/ kendali operasi untuk } \\
\text { memberi pengaturan pada } \\
\text { setiap proses dan aktivitas } \\
\text { pekerjaan dalam melayani } \\
\text { distribusi bahan ajar ke } \\
\text { mahasiswa. }\end{array}$ & $\begin{array}{l}\text { DSS03 } \\
\text { (Mengelola } \\
\text { Masalah) }\end{array}$ \\
\hline
\end{tabular}

\subsection{Perhitungan Kapabilitas Proses}

Pada kelima proses COBIT 5 terpilih, dilakukan penyebaran kuesioner evaluasi tata kelola TI berdasarkan kelima proses COBIT yaitu EDM01, EDM04, DSS01, DSS02, dan DSS03 yang telah disesuaikan dengan standar template kuesioner COBIT berdasarkan Self Asessement Guide. Responden pada penelitian ini berjumlah tujuh orang yang terdiri dari stakeholder sebagai manajemen strategis seperti Tabel 2.

Tabel 2 Responden Kuesioner Penelitian

\begin{tabular}{ll}
\hline No & Responden \\
\hline 1 & Kepala Unit Pusat Layanan Bahan Ajar \\
2 & Kepala Unit Pelaksana Teknis Teknologi Informasi \\
& Komunikasi \\
3 & Penanggung Jawab Bidang Pemeliharaan UPT TIK \\
4 & Penanggung Jawab Bidang Sistem Informasi dan Data \\
5 & Penanggung Jawab Bidang Pergudangan Bahan Ajar \\
6 & Penanggung Jawab Bidang Pengiriman Bahan Ajar \\
7 & Penanggung Jawab Bidang Administrasi dan Tata \\
& Usaha \\
\hline
\end{tabular}

Pada Tabel 2, tujuh orang responden yang merupakan stakeholder manajemen strategis dalam pengambilan keputusan diberikan instrumen evaluasi untuk seluruh objek audit COBIT 5 pada proses EDM01, EDM04,D DSS01, DSS02, dan DSS03.

Jawaban yang diberikan oleh responden terhadap pengisian dokumen kuesioner kemudian dilakukan pengukuran tingkat kapabilitas capaian evaluasi pada kelima proses terpilih dengan alat ukur Process 
Assessment Model (PAM) dan informasi peringkat atribut seperti Tabel 3 .

Tabel 3 Tingkat Kapabilitas Proses (ISACA, 2012a)

\begin{tabular}{|c|c|c|c|c|c|c|}
\hline $\begin{array}{l}\text { Tingkat } \\
\text { Kapabilitas }\end{array}$ & $\begin{array}{l}\text { Atribut } \\
\text { Proses }\end{array}$ & 1 & 2 & 3 & 4 & 5 \\
\hline $\begin{array}{l}\text { Level 1: } \\
\text { Performed }\end{array}$ & PA 1.1 & $\mathrm{~L} / \mathrm{F}$ & & & & \\
\hline Level 2: & PA & $\mathrm{F}$ & $\mathrm{L} / \mathrm{F}$ & & & \\
\hline $\begin{array}{l}\text { Managed } \\
\text { Level } 3\end{array}$ & $\begin{array}{l}2.1 \& 2.2 \\
\text { PA }\end{array}$ & $\mathrm{F}$ & $\mathrm{F}$ & $\mathrm{L} / \mathrm{F}$ & & \\
\hline $\begin{array}{l}\text { Established } \\
\text { Level 4: }\end{array}$ & $\begin{array}{l}3.1 \& 3.2 \\
\text { PA }\end{array}$ & $\mathrm{F}$ & $\mathrm{F}$ & $\mathrm{F}$ & $\mathrm{L} / \mathrm{F}$ & \\
\hline $\begin{array}{l}\text { Predictable } \\
\text { Level 5: } \\
\text { Optimizing }\end{array}$ & $\begin{array}{l}4.1 \& 4.2 \\
\text { PA } \\
5.1 \& 5.2\end{array}$ & $\mathrm{~F}$ & $\mathrm{~F}$ & $\mathrm{~F}$ & $\mathrm{~F}$ & $\mathrm{~L} / \mathrm{F}$ \\
\hline
\end{tabular}

Standar ISO/IEC 15504 menjadi standar skala penilaian yang dapat memeringkatkan setiap atribut proses COBIT 5. Pada Tabel 4 tersaji skala penilaian menurut ISO/IEC 15504.

Tabel 4 Skala Penilaian ISO/IEC 15504 (ISACA, 2012a)

\begin{tabular}{|c|c|c|}
\hline Peringkat & $\begin{array}{l}\text { Persentasi } \\
(\%)\end{array}$ & Deskripsi \\
\hline $\begin{array}{l}\mathrm{N}-\text { Not achieved } \\
\text { (Tidak Tercapai) }\end{array}$ & $0-15$ & $\begin{array}{l}\text { Tidak ada atau hanya ada } \\
\text { sedikit pencapaian dari } \\
\text { atribut proses yang dinilai. }\end{array}$ \\
\hline $\begin{array}{l}\mathrm{P}-\text { Partial achieved } \\
\text { (tercapai sebagian) }\end{array}$ & $>15-50$ & $\begin{array}{l}\text { Ada beberapa pencapaian } \\
\text { dari atribut proses yang } \\
\text { dinilai namun beberapa } \\
\text { aspek dari pencapaian atribut } \\
\text { masih belum dapat } \\
\text { diperbaiki. }\end{array}$ \\
\hline $\begin{array}{l}\mathrm{L}-\text { Largely } \\
\text { achieved } \\
\text { (Hampir Tercapai) }\end{array}$ & $>50-85$ & $\begin{array}{l}\text { Pada atribut ini ada bukti } \\
\text { usaha secara sistematis dan } \\
\text { pencapaian yang signifikan } \\
\text { dari atribut yang } \\
\text { didefinisikan dari proses } \\
\text { yang dinilai. Kelemahhan } \\
\text { yang terkait dengan atribut } \\
\text { terdapat pada proses yang } \\
\text { dinilai. }\end{array}$ \\
\hline $\begin{array}{l}\mathrm{F}-\text { Fully achieved } \\
\text { (tercapai } \\
\text { sempurna) }\end{array}$ & $>85-100$ & $\begin{array}{l}\text { Ada bukti lengkap dari } \\
\text { pendekatan sistematis, } \\
\text { pencapaian sempurna dari } \\
\text { atribut pada proses penilaian. } \\
\text { Tidak ada kelemahan } \\
\text { signifikan yang berkaitan } \\
\text { dengan atribut pada proses } \\
\text { penilaian. }\end{array}$ \\
\hline
\end{tabular}

\subsection{Hasil Analisis dan Olah Data Kuesioner}

Hasil pengukuran tingkat kapabilitas kelima proses COBIT terpilih terdapat di Tabel 5, Tabel 6, Tabel 7, Tabel 8 dan Tabel 9.

Tabel 5 Persentasi Pengukuran Proses EDM01

\begin{tabular}{|c|c|c|c|c|c|c|c|c|c|}
\hline \multirow{3}{*}{ Asesmen } & \multirow{3}{*}{$\begin{array}{l}\text { Level } \\
1(\%) \\
\text { PA } \\
1.1\end{array}$} & \multicolumn{2}{|c|}{ Level $2(\%)$} & \multicolumn{2}{|c|}{ Level $3(\%)$} & \multicolumn{2}{|c|}{ Level $4(\%)$} & \multicolumn{2}{|c|}{ Level $5(\%)$} \\
\hline & & PA & PA & PA & PA & PA & PA & PA & PA \\
\hline & & 2.1 & 2.2 & 3.1 & 3.2 & 4.1 & 4.2 & 5.1 & 5.2 \\
\hline Nilai & 52,38 & 50 & 46 , & 45 , & 45 , & 0 & 0 & 0 & 0 \\
\hline Rating & & & & & & & & & \\
\hline Level & L & L & $\mathrm{P}$ & $\mathrm{P}$ & $\mathrm{P}$ & $\mathrm{N}$ & $\mathrm{N}$ & $\mathrm{N}$ & $\mathrm{N}$ \\
\hline Level & 1 & & & & & & & & \\
\hline
\end{tabular}

Tabel 6 Persentasi Pengukuran Proses EDM04

\begin{tabular}{|c|c|c|c|c|c|c|c|c|c|}
\hline \multirow{3}{*}{ Asesmen } & \multirow{3}{*}{$\begin{array}{l}\text { Level } \\
1(\%) \\
\text { PA } \\
1.1\end{array}$} & \multicolumn{2}{|c|}{ Level $2(\%)$} & \multicolumn{2}{|c|}{ Level $3(\%)$} & \multicolumn{2}{|c|}{ Level 4 (\%) } & \multicolumn{2}{|c|}{ Level $5(\%)$} \\
\hline & & PA & PA & PA & PA & PA & PA & PA & PA \\
\hline & & 2.1 & 2.2 & 3.1 & 3.2 & 4.1 & 4.2 & 5.1 & 5.2 \\
\hline \multirow[t]{2}{*}{ Nilai } & \multirow{2}{*}{66,67} & 64 , & 64,2 & 62 , & 50 & 0 & 0 & 0 & 0 \\
\hline & & 29 & 9 & 86 & & & & & \\
\hline \multirow{3}{*}{$\begin{array}{l}\text { Rating } \\
\text { Level } \\
\text { Level } \\
\text { Kapabilitas }\end{array}$} & L & \multirow[t]{3}{*}{$\mathrm{L}$} & \multirow[t]{3}{*}{$\mathrm{L}$} & \multirow[t]{3}{*}{$\mathrm{L}$} & \multirow[t]{3}{*}{$P$} & \multirow[t]{3}{*}{$\mathrm{N}$} & \multirow[t]{3}{*}{$\mathrm{N}$} & \multirow[t]{3}{*}{$\mathrm{N}$} & \multirow[t]{3}{*}{$\mathrm{N}$} \\
\hline & 1 & & & & & & & & \\
\hline & & & & & & & & & \\
\hline
\end{tabular}

Tabel 7 Persentasi Pengukuran Proses DSS01

\begin{tabular}{|c|c|c|c|c|c|c|c|c|c|}
\hline \multirow{3}{*}{ Asesmen } & \multirow{3}{*}{$\begin{array}{l}\begin{array}{l}\text { Level } \\
1(\%)\end{array} \\
\text { PA } \\
1.1\end{array}$} & \multicolumn{2}{|c|}{ Level $2(\%)$} & \multicolumn{2}{|c|}{ Level $3(\%)$} & \multicolumn{2}{|c|}{ Level $4(\%)$} & \multicolumn{2}{|c|}{ Level $5(\%)$} \\
\hline & & $\mathrm{PA}$ & $\mathrm{PA}$ & PA & PA & $\mathrm{PA}$ & PA & PA & PA \\
\hline & & 2.1 & 2.2 & 3.1 & 3.2 & 4.1 & 4.2 & 5.1 & 5.2 \\
\hline Nilai & 67,35 & $\begin{array}{l}66, \\
67\end{array}$ & $\begin{array}{l}64,2 \\
9\end{array}$ & $\begin{array}{l}62, \\
86\end{array}$ & $\begin{array}{l}57, \\
14\end{array}$ & $\begin{array}{l}35,7 \\
1\end{array}$ & 0 & 0 & 0 \\
\hline $\begin{array}{l}\text { Rating } \\
\text { Level }\end{array}$ & L & L & L & $\mathrm{L}$ & L & $\mathrm{P}$ & $\mathrm{N}$ & $\mathrm{N}$ & $\mathrm{N}$ \\
\hline $\begin{array}{l}\text { Level } \\
\text { Kapabilitas }\end{array}$ & 1 & & & & & & & & \\
\hline
\end{tabular}

Tabel 8 Persentasi Pengukuran Proses DSS02

\begin{tabular}{|c|c|c|c|c|c|c|c|c|c|}
\hline \multirow{3}{*}{ Asesmen } & \multirow{3}{*}{$\begin{array}{l}\text { Level } \\
1(\%) \\
\text { PA } \\
1.1\end{array}$} & \multicolumn{2}{|c|}{ Level $2(\%)$} & \multicolumn{2}{|c|}{ Level $3(\%)$} & \multicolumn{2}{|c|}{ Level $4(\%)$} & \multicolumn{2}{|c|}{ Level $5(\%)$} \\
\hline & & PA & PA & PA & PA & PA & PA & PA & PA \\
\hline & & 2.1 & 2.2 & 3.1 & 3.2 & 4.1 & 4.2 & 5.1 & 5.2 \\
\hline Nilai & 85,71 & $\begin{array}{l}83, \\
33\end{array}$ & 75 & $\begin{array}{l}65, \\
71\end{array}$ & $\begin{array}{l}61, \\
90\end{array}$ & $\begin{array}{l}59,5 \\
2\end{array}$ & $\begin{array}{l}28, \\
57\end{array}$ & 0 & 0 \\
\hline $\begin{array}{l}\text { Rating } \\
\text { Level }\end{array}$ & F & $\mathrm{L}$ & $\mathrm{L}$ & $\mathrm{L}$ & $\mathrm{L}$ & $\mathrm{L}$ & $\mathrm{P}$ & $\mathrm{N}$ & $\mathrm{N}$ \\
\hline $\begin{array}{l}\text { Level } \\
\text { Kapabilitas }\end{array}$ & & & & & & & & & \\
\hline
\end{tabular}

Tabel 9 Persentasi Pengukuran Proses DSS03

\begin{tabular}{|c|c|c|c|c|c|c|c|c|c|}
\hline \multirow{3}{*}{ Asesmen } & \multirow{3}{*}{$\begin{array}{l}\text { Level } \\
1(\%) \\
\text { PA } \\
1.1\end{array}$} & \multicolumn{2}{|c|}{ Level $2(\%)$} & \multicolumn{2}{|c|}{ Level $3(\%)$} & \multicolumn{2}{|c|}{ Level 4 (\%) } & \multicolumn{2}{|c|}{ Level $5(\%)$} \\
\hline & & PA & PA & PA & PA & PA & PA & PA & PA \\
\hline & & 2.1 & 2.2 & 3.1 & 3.2 & 4.1 & 4.2 & 5.1 & 5.2 \\
\hline Nilai & 85,71 & $\begin{array}{l}85, \\
71\end{array}$ & $\begin{array}{l}82,1 \\
4\end{array}$ & $\begin{array}{l}57, \\
14\end{array}$ & $\begin{array}{l}33, \\
33\end{array}$ & $\begin{array}{l}19,0 \\
5\end{array}$ & 0 & 0 & 0 \\
\hline $\begin{array}{l}\text { Rating } \\
\text { Level }\end{array}$ & F & $\mathrm{F}$ & L & L & P & $\mathrm{P}$ & $\mathrm{N}$ & $\mathrm{N}$ & $\mathrm{N}$ \\
\hline $\begin{array}{l}\text { Level } \\
\text { Kapabilitas }\end{array}$ & & & & & & & & & \\
\hline
\end{tabular}

\subsection{Analisis Kesenjangan Kapabilitas Proses}

Hasil analisis yang diperoleh terkait kesenjangan (gap) adalah nilai pada kemampuan proses tata kelola TI saat ini pada layanan bahan ajar UT pada proses-proses COBIT yang dievaluasi dengan nilai kemampuan yang ingin dicapai. Target atau capaian kapabilitas proses evaluasi tata kelola teknologi informasi yang diharapkan ada pada level 5 yaitu Optimizing Process, dimana organisasi mampu untuk melakukan dan memiliki inovasiinovasi serta membuat otomasi dalam bidang teknologi informasi yang dapat mendukung proses operasional layanan SITTA yang ada pada Unit Pusat Layanan Bahan Ajar Universitas Terbuka. Selain itu juga diharapkan mampu dalam melakukan perbaikan berkelanjutan untuk meningkatkan kemampuan teknologi informasi yang dapat terintegrasi dengan semua aktivitas bisnis dan operasional organisasi agar kinerja organisasi menjadi efektif, efisien, dan transparan.

Selain itu organisasi juga diharapkan mampu menjalankan dengan baik standar khusus atau Standar Operasional Prosedur (SOP) yang terdefinisi dari kebijakan terkait dengan aktivitas operasional 
dan pengembangan teknologi informasi pada Unit Layanan Bahan Ajar - UT untuk mencapai tujuan organisasi dari proses hulu ke hilir pada setiap aktivitas bisnis dan operasional. Gambar 3 berikut diagram visualisasi kesenjangan/ gap antara capaian tingkat kapabilitas proses saat ini dengan nilai harapan/ target yang ingin dicapai.

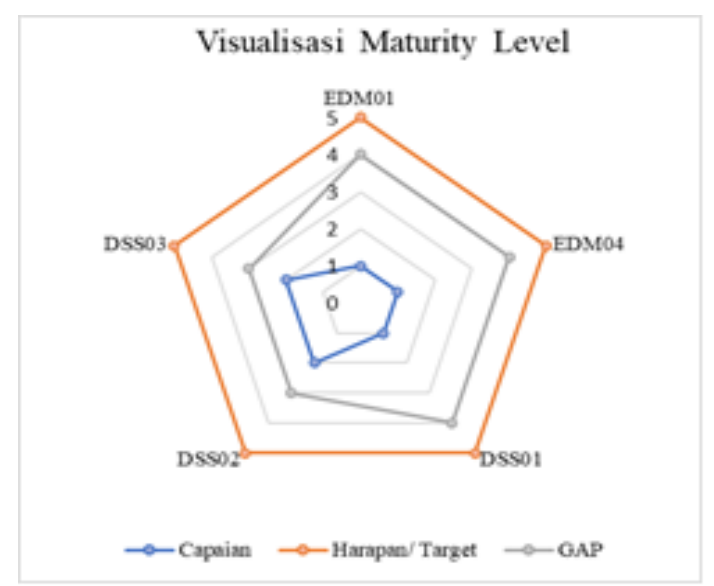

Gambar 3 Visualisasi Analisis Kesenjangan

Hasil analisis kesenjangan ( ap) yang diperoleh seperti pada Tabel 10 .

Tabel 10 Hasil Gap Analisis

\begin{tabular}{lllll}
\hline No & Proses & Capaian Kapabilitas & Target & Gap \\
\hline 1 & EDM01 & 1 (performed process) & 5 & 4 \\
2 & EDM04 & 1 (performed process) & 5 & 4 \\
3 & DSS01 & 1 (performed process) & 5 & 4 \\
4 & DSS02 & 2 (managed process) & 5 & 3 \\
5 & DSS03 & 2 (managed process) & 5 & 3 \\
\hline
\end{tabular}

\subsection{Prioritas Proses Perbaikan}

\subsubsection{Menentukan Kriteria Prioritas Perbaikan}

Kriteria diperoleh dari hasil diskusi dengan Penanggung Jawab Bidang Sistem Informasi Data pada Unit Pusat Layanan Bahan Ajar. Kriteria diperoleh dari hal-hal apa saja yang harus diperhatikan pada saat pelaksanaan perbaikan proses COBIT 5. Penentuan bobot kriteria ditentukan berdasarkan pada hasil Kuesioner Prioritas Matriks seperti penelitian sebelumnya oleh (Hidayat, 2018). Pada hasil perhitungan prioritas matriks, skala nilai untuk masing-masing kriteria akan dikalikan terhadap nilai bobot yang diperoleh (Indriati, 2014). Kriteria pemilihan proses untuk dijadikan prioritas perbaikan menggunakan skala nilai (1-9) pada 4 butir kriteria seperti pada Tabel 11.

Tabel 11 Nilai Bobot Kriteria Prioritas Proses (skala 1-9)

\begin{tabular}{lll}
\hline $\begin{array}{l}\text { No. } \\
\text { Kriteria }\end{array}$ & Kriteria & Bobot (skala 1-9) \\
\hline 1 & $\begin{array}{l}\text { Dampak positif penerapan } \\
\text { proses }\end{array}$ & 8 \\
2 & $\begin{array}{l}\text { Kemudahan implementasi } \\
\text { dilihat dari upaya yang harus }\end{array}$ & 7 \\
\hline
\end{tabular}

\begin{tabular}{lll}
\hline $\begin{array}{l}\text { No. } \\
\text { Kriteria }\end{array}$ & Kriteria & Bobot (skala 1-9) \\
\hline & dilakukan & \\
3.1 & $\begin{array}{l}\text { Kesiapan organisasi terhadap } \\
\text { sumber daya manusia }\end{array}$ & 5 \\
3.2 & $\begin{array}{l}\text { Kesiapan organisasi terhadap } \\
\text { teknologi }\end{array}$ & 7 \\
4 & Kepatuhan terhadap aturan & 8 \\
\hline
\end{tabular}

Tabel 11 merupakan hasil perhitungan skor dengan nilai dari kriteria untuk tiap proses COBIT 5 yang terpilih. Skor berasal dari hasil pengisian kuesioner oleh responden yaitu Kepala Unit Pusat dan Penanggung Jawab Bidang Sistem Informasi Data di Unit Layanan Bahan Ajar, dikalikan dengan bobot nilai ke 4 proses terpilih.

Tabel 12 Hasil Pengukuran Prioritas Proses COBIT

\begin{tabular}{|c|c|c|c|c|c|c|}
\hline \multirow[t]{2}{*}{ Proses } & \multicolumn{5}{|c|}{ Kriteria } & \multirow[t]{2}{*}{ Total } \\
\hline & $\begin{array}{l}\text { Dam } \\
\text { pak } \\
\text { (1) }\end{array}$ & $\begin{array}{l}\text { Kemudahan } \\
\text { Implementa } \\
\text { si (2) }\end{array}$ & $\begin{array}{l}\text { SDM } \\
(3.1)\end{array}$ & $\begin{array}{l}\text { Tekno } \\
\text { logi } \\
(3.2)\end{array}$ & $\begin{array}{l}\text { Atur } \\
\text { an } \\
\text { (4) }\end{array}$ & \\
\hline $\begin{array}{l}\text { EDM } \\
01\end{array}$ & 72 & 42 & 25 & 35 & 40 & 214 \\
\hline $\begin{array}{l}\text { EDM } \\
04\end{array}$ & 72 & 42 & 25 & 35 & 40 & 214 \\
\hline $\begin{array}{l}\text { DSS } \\
01\end{array}$ & 72 & 42 & 25 & 35 & 40 & 214 \\
\hline $\begin{array}{l}\text { DSS } \\
02\end{array}$ & 72 & 49 & 25 & 35 & 40 & 221 \\
\hline $\begin{array}{l}\text { DSS } \\
03\end{array}$ & 72 & 49 & 25 & 35 & 40 & 221 \\
\hline
\end{tabular}

Tabel 12 memiliki penjelasan sebagai berikut:

1. Kolom Dampak: merupakan kolom yang berisi nilai kriteria "Dampak Positif Penerapan Dari Proses" pada tiap proses COBIT 5 terpilih (EDM0, EDM04, DSS01, DSS02, dan DSS03). Kolom ini diperoleh dari hasil perhitungan skor jawaban yang diisi oleh responden dikalikan bobot yang diperoleh pada Tabel 11. Sebagai contoh perolehan total di Proses EDM01:

(skor jawaban $=9$, bobot yang diperoleh $=8$, hasil pengukuran $9 \times 8=72$ ).

2. Kolom Kemudahan Implementasi: merupakan kolom yang berisi nilai kriteria "Kemudahan Implementasi Dilihat Dari Upaya Yang Harus Dilakukan" pada tiap proses COBIT 5 terpilih (EDM0, EDM04, DSS01, DSS02, dan DSS03). Kolom ini diperoleh dari hasil perhitungan skor jawaban yang diisi oleh responden dikalikan bobot yang diperoleh pada Tabel 11, Sebagai contoh perolehan total di Proses EDM01:

(skor jawaban $=6$, bobot yang diperoleh $=7$, hasil pengukuran $6 \times 7=42$ ).

3. Kolom Kriteria SDM: merupakan kolom yang berisi nilai kriteria "Kesiapan Organisasi Terhadap Sumber Daya Manusia” pada tiap proses COBIT 5 terpilih (EDM0, EDM04, DSS01, DSS02, dan DSS03). Kolom ini diperoleh dari hasil perhitungan skor jawaban 
yang diisi oleh responden dikalikan bobot yang diperoleh pada Tabel 11. Sebagai contoh perolehan total di Proses EDM01:

( kor jawaban $=5$, bobot yang diperoleh $=5$, hasil pengukuran $5 \times 5=25$ ).

4. Kolom Teknologi: merupakan kolom yang berisi nilai kriteria "Kesiapan Organisasi Terhadap Teknologi” pada tiap proses COBIT 5 terpilih (EDM0, EDM04, DSS01, DSS02, dan DSS03). Kolom ini diperoleh dari hasil perhitungan skor jawaban yang diisi oleh responden dikalikan bobot yang diperoleh pada Tabel 11. Sebagai contoh perolehan total di Proses EDM01:

( skor jawaban $=5$, bobot yang diperoleh $=7$, hasil pengukuran $5 \times 7=35$ ).

5. Kolom Aturan: merupakan kolom yang berisi nilai kriteria "Kepatuhan terhadap aturan" pada tiap proses COBIT 5 terpilih (EDM0, EDM04, DSS01, DSS02, dan DSS03). Kolom ini diperoleh dari hasil perhitungan skor jawaban yang diisi oleh responden dikalikan bobot yang diperoleh pada Tabel 11. Sebagai contoh perolehan total di Proses EDM01:

(skor jawaban $=5$, bobot yang diperoleh $=8$, hasil pengukuran $5 \times 8=40$ ).

Dari Tabel 12 proses DSS02 dan DSS03 memperoleh urutan prioritas paling besar dengan jumlah total nilai terbesar yaitu 221 pada proses mengelola permintaan layanan dan insiden TI dan proses pengelolaan masalah pada unit layanan bahan ajar UT. Hal ini menunjukkan bahwa Unit Pusat Layanan Bahan Ajar lebih berorientasi pada layanan, baik terhadap permintaan pengguna sistem terkait aplikasi dan layanan insiden TI serta layanan kepada mahasiswa yang berhubungan dengan operasional penanganan fasilitas yang berkaitan dengan memanfaatan TI pada pemesanan bahan ajar serta manajemen pengelolaan masalah lainnya.

\subsection{Rekomendasi Perbaikan}

Rekomendasi perbaikan dilakukan berdasarkan urutan prioritas yaitu pada proses yang memiliki nilai kesenjangan/ gap paling kecil sehingga proses lebih mudah untuk dimplementasikan ke sistem.

Tabel 13 Rekomendasi Proses DSS02

No Rekomendasi Proses DSS02

1 Menyediakan pengawasan lebih lanjut pada efektifitas proses untuk mendukung tujuan organisasi.

2 Mengembangkan aplikasi SITTA untuk internal dan aplikasi untuk mahasiswa untuk fitur fasilitas tracking/ lacak status pengiriman bahan ajar secara khusus (tracking keberadaan bahan ajar saat dikirim oleh kurir pengiriman saat pengiriman berlangsung) yang dapat dilacak/ dipantau oleh mahasiswa yang memesan dan membeli bahan ajar ke UT.

3 Melakukan identifikasi dan pendefinisian terhadap permintaan layanan dan insiden yang terjadi terkait layanan TI, implementasi aplikasi seperti penambahan fitur aplikasi, maintenance sistem secara berkala, dan kebutuhan infrastruktur TI di Unit Pusat Layanan Bahan Ajar.

Tabel 14 Rekomendasi Proses DSS03

\begin{tabular}{ll}
\hline No & Rekomendasi Proses DSS03 \\
\hline 1 & Menyediakan pengaturan/ rules yang jelas dan sesuai \\
& standar SOP yang terkait dengan pengambilan barang/ \\
& order picking berikut dengan pengembangan/ inovasi \\
& TI untuk optimalisasi kinerja proses ke depan, \\
& sehingga proses order picking tidak hanya \\
& mengandalkan preferensi dari petugas yang \\
& ditugaskan. Misalnya mekanisme pembagian \\
& kelompok untuk proses belanja/ order picking bahan \\
ajar dan pengembangan Artificial Intelligence berbasis \\
aplikasi untuk optimasi proses ini. \\
\hline Menyediakan pengelolaan pengembangan berbasis \\
sistem real-time pada proses pengelolaan data baik \\
proses input, delete maupun update data, mekanisme \\
hak akses, dan hal terkait pengelolaan data lainnya \\
pada aktivitas operasional di Unit Pusat Layanan \\
Bahan Ajar. \\
Menyediakan sistem kontrol/ kendali operasi untuk \\
memberi pengaturan pada setiap proses dan aktivitas \\
pekerjaan dalam melayani distribusi bahan ajar ke \\
mahasiswa di Unit Pusat Layanan Bahan Ajar.
\end{tabular}

Tabel 15 Rekomendasi Proses EDM01

No Rekomendasi Proses EDM01

1 Pelaksanaan pengembangan Teknologi Informasi dapat memiliki master perencanaan yang baik ke depan untuk meningkatkan kualitas layanan bahan ajar ke mahasiswa. Selain itu dalam pelaksanaan Standar Operasional Prosedur (SOP) dapat dilakukan mekanisme yang jelas terkait pengembangan dan pemeliharaan tata kelola TI agar ke depannya dapat sesuai dengan rencana strategis UT pada capaian tata kelola TI, khususnya di Unit Pusat Layanan Bahan Ajar.

2 Melaksanakan praktik yang berkaitan dengan pengoptimalan pemanfaatan TI, seperti penggunaan sistem berbasis mobile apps sebagai supporting portable device pada aktivitas operasional layanan bahan ajar di Unit Pusat Layanan Bahan Ajar.

3 Melakukan evaluasi optimalisasi dari pemanfaatan teknologi informasi yang telah digunakan.

Tabel 16 Rekomendasi Proses EDM04

No Rekomendasi Proses EDM04

1 Menambah jumlah SDM khusus bidang TI yang memiliki keterampilan dan literasi TI yang baik dan kompeten pada Unit Pusat Layanan Bahan Ajar Universitas Terbuka.

2 Membentuk tim/ staf khusus bagian TI yang dapat membantu aktivitas operasional di Unit Pusat Layanan Bahan Ajar sekaligus mengembangkan dan melakukan inovasi-inovasi terkait perbaikan sistem dan kebutuhan

pengembangan aplikasi secara internal di Unit Puslaba.

3 Memberikan pelatihan khusus untuk keahlian dan keterampilan dalam bidang SI/ TI kepada staf di Unit Puslaba agar mengetahui dan menjadi terampil dengan pelatihan yang diberikan.

Tabel 17 Rekomendasi Proses DSS01

\begin{tabular}{ll}
\hline No & Rekomendasi Proses DSS01 \\
\hline 1 & Menyediakan layanan berbasis Teknologi Informasi \\
& seperti implementasi pada mobile apps sebagai inovasi \\
& layanan berbasis portable device yang dapat
\end{tabular}




\begin{tabular}{ll}
\hline No & Rekomendasi Proses DSS01 \\
\hline & mempermudah proses belanja/ order picking \\
& (pengambilan bahan ajar di Gudang) dengan layanan \\
& fitur scan QR Code nomor pemesanan (DO) dan \\
& lokasi \\
& item BA, sehingga proses diharapkan menjadi lebih \\
& efektif. \\
& Memberikan teknologi berbasis algoritma dengan \\
& penerapan pada aplikasi mobile apps sebagai \\
& supporting portable device untuk mendukung \\
& efektivitas proses belanja berdasarkan batching system \\
& dengan melakukan cluster terhadap nomor DO bahan \\
& ajar yang memiliki kemiripan barang dan lokasi yang \\
& sama menjadi satu nomor batch DO. \\
\hline 3 & Membuat Standar Operasional Prosedur yang jelas \\
dan menjalankan tugas operasional dengan konsisten \\
dan tanggung jawab yang benar.
\end{tabular}

Proses EDM01, EDM04, dan DSS01 dapat mencapai kapabilitas level 2 apabila dievaluasi dan memenuhi pelaksanaan indikator kerja sebagai berikut (Dewantara, 2015)

Indikator PA 2.1 Performance Management:

1. Dapat melakukan identifikasi dengan baik terhadap sasaran kinerja proses secara objektif.

2. Kinerja proses terencana dan termonitor dengan baik pada perencanaan proses.

3. Terdapat penyesuaian kinerja proses untuk memenuhi perencanaan yang dibuktikan dengan dokumentasi/ rekaman kualitas dari kinerja.

4. Organisasi dapat mendefinisikan dan mendokumentasikan mekanisme tanggung jawab dan wewenang untuk menjalankan proses (EDM01, EDM04, dan DSS01).

5. Tersedia dan teralokasi dengan baik sumber daya dan informasi yang dibutuhkan organisasi untuk melakukan proses identifikasi tata kelola TI dengan adanya dokumen perencanan.

6. Mengelola interaksi pihak-pihak terkait untuk memastikan bahwa komunikasi berjalan secara efektif dan adanya penugasan yang jelas terhadap tanggung jawab serta terbukti dengan dokumentasi dan perencanaan proses.

Indikator PA 2.2 Work Product Management:

1. Persyaratan dari proses sudah terdefinisikan yang ditandai dengan adanya perencanaan kualitas.

2. Persyaratan dokumentasi dan kontrol dari work product sudah terdefinisi yang ditandai dengan adanya dokumentasi proses dan perencanaan kualitas.

3. Work product telah diidentifikasi, didokumentasikan, dan dikontrol dengan baik.

4. Work product yang dihasilkan dikaji sesuai dengan perencanaan dan pesyaratan yang diharapkan.

Proses EDM01, EDM04, DSS01, DSS02, dan DSS03 harus memenuhi dan melaksanakan indikator kerja untuk dapat meningkatkan kapabilitas dari level 2 ke level 3. (Dewantara, 2015) menjelaskan poin-poin indikator kerja untuk mencapai target organisasi tingkat kapabilitas level 3 yaitu:
Indikator PA 3.1 Process Definition:

1. Standar dalam proses sudah ada, disertai dengan panduan-panduan untuk modifikasi TI.

2. Adanya standar urutan dan cara interaksi diantara sub-proses atau proses-proses lain.

3. Adanya standar penilaian kompetensi dan peran untuk menjalankan proses TI telah ada.

4. Standar dari penilaian lingkungan kerja dan infrastruktur dalam menjalankan proses TI telah ada.

5. Telah ada pengawasan efektifitas proses yang sesuai dengan proses TI.

Indikator PA 3.2 Proses Deployment:

1. Adanya data dan informasi dari pelaksanaan proses untuk mendukung tujuan organisasi.

2. Menggunakan data dan informasi dari pelaksanaan proses untuk alat ukur kinerja pelaksanaan.

3. Pengukuran kuantitatif digunakan terhadap kinerja yang relevan dengan masing-masing tujuan bisnis.

4. Adanya penyesuaian unit ukuran proses dengan model output dari proses tersebut, dan frekuensi pengukuran proses disesuaikan dengan model kuantitatif penilaian kinerja proses tersebut.

5. Pengumpulan dan analisis terhadap hasil pengukuran dilaporkan untuk memonitor secara kuantitatif kualitas dari kinerja proses apakah telah tercapai atau belum.

6. Mencari karakteristik pola tertentu dalam proses menggunakann hasil pengukuran kapabilitas.

Proses EDM01, EDM04, DSS01, DSS02, dan DSS03 harus memenuhi dan melaksanakan indikator kerja untuk dapat meningkakan kapabilitas dari level 3 ke level 4. Poin-poin indikator kerja untuk mencapai target organisasi tingkat kapabilitas level 4 adalah (Dewantara, 2015)

PA 4.1 Process Measurement:

1. Kebutuhan proses informasi telah tersedia lengkap dengan tujuan organisasi yang relevan.

2. Kebutuhan proses internal yang menjadi tujuan dari pengukuran proses telah terpenuhi dengan baik.

3. Peningkatan performa organisasi telah dapat dilaksanakan sebagai tujuan organisasi.

4. Terdapat identifikasi pengukuran dan frekuensi performa proses secara terstruktur.

5. Hasil dari pengukuran proses dapat dilakukan analisis, pengumpulan dan pelaporan untuk memantau tujuan organisasi kepada stakeholder.

6. Dapat dilakukan gambaran performa proses pada hasil pengukuran proses.

PA 4.2 Process Control:

1. Telah dapat dilakukan pengaplikasian kontrol dan teknik analisis pada kinerja proses. 
2. Telah dapat menetapkan standar performa proses dalam keadaan normal.

3. Analisis pengukuran data dapat menjadi penyebab khusus adanya suatu variasi dalam implementasi kinerja proses.

4. Adanya tindakan korektif sebagai cara untuk mengetahui penyebab khusus dari variasi pada kinerja proses.

5. Adanya sistem kontrol untuk membatasi respon pada tindakan korektif pada kinerja proses.

Proses EDM01, EDM04, DSS01, DSS02, dan DSS03 harus memenuhi dan melaksanakan indikator kerja untuk dapat meningkakan kapabilitas dari level 4 ke level 5. Menurut (Dewantara, 2015), poin-poin indikator kerja untuk mencapai target organisasi tingkat kapabilitas level 5 sebagai berikut:

PA 5.1 Process Innovation:

1. Terdapat tujuan bisnis/ organisasi yang inovatif sebagai capaian untuk kebutuhan organisasi di masa perkembangan TI ke depan.

2. Mampu melakukan ketepatan analisis untuk mengetahui performa proses yang diterapkan.

3. Terdapat inovasi dan wawasan terbaik untuk melaksanakan aktivitas operasional dan analisis data.

4. Adanya proses yang didefinisikan untuk meningkatkan inovasi pada pengembangan teknologi baru.

5. Meningkatkan strategi implementasi kinerja proses untuk memenuhi tujuan organisasi.

PA 5.2 Process Optimising:

1. Memiliki teknis analisis dan kontrol pada pengelolaan proyek pada pengembangan sistem informasi dan teknologi.

2. Menerapkan variasi limit kontrol pada proses pengelolaan proyek pengembangan sistem informasi dan teknologi.

3. Dapat dilakukan aktifitas menganalisis data yang sudah diukur untuk memperoleh variasi yang unik pada proses pengelolaan proyek pengembangan sistem informasi dan teknologi.

\section{KESIMPULAN DAN SARAN}

Implementasi tata kelola layanan teknologi informasi menggunakan kerangka kerja COBIT 5 dengan studi kasus Sistem Informasi Tiras dan Transaksi Bahan ajar di lingkup Unit Pusat Layanan Bahan Ajar memperoleh tingkat kapabilitas level 1 (performed process) untuk proses EDM01, EDM04, dan DSS01 dengan hasil persentase kapabilitas proses EDM01 sebesar 52,38 \%, EDM04 66,67 \%, dan DSS01 67,35 \%. Hasil pencapaian tingkat kapabilitas untuk proses DSS02 dan DSS03 yaitu berada pada level 2 (managed process) dengan hasil persentase kapabilitas untuk DSS02 dan DSS03 yaitu $85,71 \%$. Nilai harapan tingkat kapabilitas yang dihasilkan adalah berada pada level 5 (optimizing process). Hal ini dapat diartikan organisasi belum sepenuhnya menerapkan beberapa best practices untuk tujuan proses COBIT 5 terpilih, telah terdapat standar layanan tata kelola TI namun belum diimplementasikan secara maksimal.

Beberapa saran yang dapat ditindaklanjuti dan dilakukan untuk kepentingan pengembangan penelitian selanjutnya di kemudian hari, diantaranya adalah usulan tata kelola rekomendasi aktivitas kebijakan tata kelola layanan TI yang diperoleh diharapkan dapat menjadi referensi prosedur monitoring dan pengukuran kemampuan TI di layanan bahan ajar Universitas Terbuka yang lebih bersifat efektif dan implementatif, unit Pusat Layanan bahan ajar mampu mempersiapkan sumber daya dan lingkungan kerja yang secara maksimal dapat mengimplementasikan layanan berbasis teknologi informasi untuk mendukung pengembangan sistem yang baik, dan Unit Pusat Layanan Bahan Ajar dapat melakukan perancangan tata kelola dengan suatu standar tertentu yang telah dilengkapi dengan panduan-panduan yang baik seperti pada COBIT 5. Dengan begitu, aktivitas operasional untuk melayani bahan ajar dapat menciptakan efektivitas dan efisiensi dalam implementasi tata kelola layanan TI, serta ke depannya perlu melakukan implementasi evaluasi tata kelola TI juga untuk perbaikan sistem secara merata pada 39 lokasi UPBJJ UT.

\section{DAFTAR PUSTAKA}

ARDIMA, M. B., GERNOWO, R., \& SLAMET, V. G. 2020. Pengukuran Tingkat Kapabilitas Sistem Tata Kelola Ti Menggunakan Cobit 5 Dengan Iso 38500 Capability Level Measurement of It Governance System Using Cobit 5 With Iso 38500. 7(3), 645-652. https://doi.org/10.25126/jtiik.202073059

ASTUTI, M. W., SUPRAPTO, \& PERDANAKUSUMA, A. R. 2019. Evaluasi Teknologi Informasi menggunakan COBIT 5 Fokus Proses DSS02, DSS03, dan DSS04 ( Studi Kasus : PT . Garam ( Persero )). Jurnal Pengembangan Teknologi Informasi Dan Ilmu Komputer, 3(9), 8874-8881.

DEWANTARA, A. D. 2015. Pengukuran Tingkat Kapabilitas Tata Kelola Teknologi Informasi Berdasarkan COBIT 5 Studi Kasus Pusat Data dan Informasi (Pusdatin) Arsip Nasional Republik Indonesia (ANRI). 314.

FAJARWATI, S., SARMINI, S., \& SEPTIANA, Y. 2018. Evaluasi Tata Kelola Teknologi Informasi Menggunakan Kerangka Kerja COBIT 5. JUITA: Jurnal Informatika, 6(2), 73. https://doi.org/10.30595/juita.v6i2.2019

FENNY, C., \& JOHANES, A. 2017. Audit Sistem Informasi Menggunakan Framework Cobit 4.1 Pada PT. Aneka Solusi Teknologi. Simetris: Jurnal Teknik Mesin, Elektro Dan Ilmu Komputer, $\quad 8(1), \quad 377-382$. https://doi.org/10.24176/simet.v8i1.1024 
HIDAYAT, A. 2018. Model Pengukuran Tingkat Kemampuan Teknologi Informasi.

INDRIATI, S. S. 2014. Evaluasi Tata Kelola Teknologi Informasi Berdasarkan Kerangka Kerja Cobit 5 : Studi Kasus Direktorat Jendral Administrasi Hukum Umum (Ditjen AHU). In Tesis, MTI Universitas Indonesia. Universitas Indonesia.

ISACA. 2012a. Enabling Processes.

ISACA. 2012b. Preview Version. COBIT 5 for Information Security.

ISACA. 2013. COBIT ® Process Assessment Model (PAM): Using COBIT ${ }^{\circledR} 5$.

IT, GOVERNANCE, \& INSTITUTE. 2012. COBIT 4.1 Framework, Control Objectives, Management Guidelines, Maturity Models. USA : IT Governance Institute.

NYONAWAN, M., SUHARJITO, \& UTAMA, D. N. 2018. Evaluation of Information Technology Governance in STMIK Mikroskil Using COBIT 5 Framework. Proceedings of 2018 International Conference on Information Management and Technology, ICIMTech 2018, November, 137-142. https://doi.org/10.1109/ICIMTech.2018.85281 38

PUTRI, L. D. M., PERDANAKUSUMA, A. R., \& RACHMADI, A. 2019. Evaluasi Maturitas Manajemen Risiko Teknologi Informasi Menggunakan Process Assessment Model COBIT 5 (Studi Kasus PT . XYZ Indonesia). Jurnal Pengembangan Teknologi Informasi Dan Ilmu Komputer, 3(6), 6089-6098. http://jptiik.ub.ac.id/index.php/jptiik/article/download/5647/2673

SURJANDY, FERNANDO, E., CONDROBIMO, A. R., \& YUDHO, M. R. 2020. Evaluasi Penerapan It Governance Pada Bank Berdasarkan Cobit 5 ( Study Kasus Pada Bank Xyz ) Evaluation Implementaion Of It Governance At Bank Xyz Based On Cobit 5 ( case study at bank xyz ). Jurnal Teknologi Dan Ilmu Komputer (JTIIK), 7(3), 453-460. https://doi.org/10.25126/jtiik.202071457

UNIVERSITAS TERBUKA. 2019. Tentang UT. Retrieved 19 September 2019, from www.ut.ac.id website: https://www.ut.ac.id/tentang-ut.

UNIVERSITAS TERBUKA. 2016. Layanan Bahan Ajar Universitas Terbuka. from http://kupang.ut.ac.id/index.php/seputarberita/layananbahan-ajar. 